\title{
Up-regulation of insulin-like growth factor-binding protein 3 by 5 -fluorouracil (5-FU) leads to the potent anti-proliferative effect of androgen deprivation therapy combined with 5-FU in human prostate cancer cell lines
}

\author{
RUMI KAWABATA ${ }^{1,2}$, SHINJI OIE $^{2}$, MASAYUKI TAKAHASHI ${ }^{3}$, \\ HIROOMI KANAYAMA ${ }^{3}$, TOSHINORI OKA ${ }^{2}$ and KOHJI ITOH $^{1}$ \\ ${ }^{1}$ Department of Medicinal Biotechnology, Institute for Medicinal Resources, \\ Graduate School of Pharmaceutical Sciences, The University of Tokushima; \\ ${ }^{2}$ Tokushima Research Center, Taiho Pharmaceutical Co., Ltd.; ${ }^{3}$ Department of Urology, \\ Institute of Health Biosciences, The University of Tokushima Graduate School, Tokushima, Japan
}

Received December 8, 2010; Accepted January 12, 2011

DOI: $10.3892 /$ ijo.2011.991

\begin{abstract}
In this study, we investigated the synergistic mechanism of anti-androgen and 5-fluorouracil (5-FU) combination therapy against castration-resistant prostate cancer (CRPC). Four prostate cancer cell lines, LNCaP, 22Rv1, DU145 and PC3, were examined for their growth dependency on androgens and the insulin-like growth factor 1 (IGF1). We assessed the expression changes of certain growth factor receptors and regulating proteins when treated with 5-FU, and found that 5-FU increased the expression of the IGF-binding protein 3 (IGFBP3). Furthermore, 5-FU inhibited the phosphorylation of Akt and p70 S6K, while the knockdown of IGFBP3 reduced the levels of poly (ADP-ribose) polymerase cleaved by $5-\mathrm{FU}$ in $\mathrm{PC} 3$ cells. Therefore, the up-regulation of IGFBP 3 by 5 -FU not only inhibits cell growth by reducing the IGF1 signal but also induces apoptosis in PC 3 cells. The synergistic effect of bicalutamide and 5-FU on 22Rv1 cells was reduced by IGFBP3 gene silencing using small-interfering RNA. These results suggest that the up-regulation of IGFBP3 induced by 5 -FU plays an important role in the potent antitumor effect of 5-FU combined with anti-androgens on CRPC. Androgen-deprivation therapy combined with 5-FU could therefore be an appropriate therapy for CRPC patients.
\end{abstract}

Correspondence to: Dr Rumi Kawabata, Tokushima Research Center, Taiho Pharmaceutical Co., Ltd., 224-2 Ebisuno, Hiraishi, Kawauchi-cho, Tokushima 771-0194, Japan

E-mail: rumi-kawabata@taiho.co.jp

Key words: 5-fluorouracil, anti-androgen drug, insulin-like growth factor-binding protein 3 , prostate cancer

\section{Introduction}

Prostate cancer is the second most frequently diagnosed cancer in men worldwide (1), and its incidence and resultant mortality rates have been increasing rapidly in Japan (2). The growth of most prostate cancers depends on the presence of androgens. Therefore, in its initial stage, prostate cancer is responsive to androgen-deprivation therapy, which can be achieved by surgical or medical castration, such as maximum androgen blockade (MAB) therapy $(3,4)$. However, most prostate cancers acquire resistance to continuing androgendeprivation therapy, and long-term survival rates are poor (5). Nevertheless, alternative (second-line) MAB therapy has been shown to be effective in some cases $(5,6)$.

Over the years, the microtubule-stabilizing agent, docetaxel, has been used with second-line therapy for castration-resistant prostate cancer (CRPC). Tannock et al demonstrated that combined docetaxel and prednisone treatment improved survival by 2.4 months on average compared to mitoxantrone with prednisone (7), while Petrylak et al reported similar findings with docetaxel and estramustine compared to mitoxantrone and prednisone (8). Taxane-based chemotherapy is currently the standard treatment for CRPC, but the increased toxicity of these combination therapies has been reported. There is thus a need for more effective, low-toxicity combined therapy, particularly because CRPC patients are usually of an advanced age.

5-fluorouracil (5-FU) is the most widely used antimetabolite in the treatment of colorectal, breast and other major types of cancer. 5-FU has two major anti-tumor mechanisms: Its active metabolite, 5-fluoro-2'-deoxyuridine5'-monophosphate, inhibits thymidylate synthase activity and consequently DNA synthesis, while the incorporation of 5-FU-derived metabolic species into RNA and DNA disrupts normal RNA processing and function. A number of orally bioavailable 5-FU derivatives have been developed and used clinically, including the following: S-1, which comprises of 
tegafur (FT), 5-chloro-2,4-dihydroxypyridine, and potassium oxonate; Xeloda (capecitabine); UFT, which comprises of FT and uracil; 1-hexylcarbamoyl-5-fluorouracil; and 5'-deoxy-5fluorouridine.

At the 2010 American Society of Clinical Oncology (ASCO) annual meeting, we reported that combination therapy with UFT and second-line MAB was significantly more effective in terms of the prostate-specific antigen (PSA) response rate $(70.6 \%)$ than second-line MAB therapy alone $(36.8 \%)(\mathrm{p}=0.054)$ in a study of 53 CRPC patients. Our study found no severe adverse effects and excellent therapeutic benefits (ASCO Annual Meeting abs. e15030, 2010; http://abstract.asco.org/ AbstView_74_42670.html).Combined UFT and MAB therapy also resulted in a significantly longer median progression-free survival (PFS) time (16.1 months) than MAB therapy alone (6.4 months) ( $\mathrm{p}=0.0028)$.

The progression of prostate cancer to CRPC possibly involves the reactivation of androgen signaling in cancer cells $(9,10)$. The androgen receptor (AR) is also overexpressed, mutated, or genomically amplified in a large number of CRPC patients. Various mechanisms have been proposed for residual androgen signaling in a low androgen environment, including the expression of transcriptionally active variant forms of AR without androgens $(11,12)$, the acquired ability of tumor cells to synthesize androgens endogenously $(13,14)$, and the activation of aberrant AR transcriptional activity through cross-talk with alternate signaling pathways $(15,16)$. For instance, insulin-like growth factor 1 (IGF1) enhances AR transactivation under low/absent androgen conditions $(17,18)$ and promotes prostate tumor cell proliferation (19).

The IGF-binding protein 3 (IGFBP3) is one of the six members of the IGFBP family and the major serum carrier of IGF1 and IGF2 (20,21). IGFBP3 and IGFBP5 circulate predominantly in a ternary complex with IGF and the acidlabile subunit (ALS) $(20,21)$. IGFBP3 regulates IGF1 and IGF2 bioactivity by sequestering them away from their receptor IGF1R, and inhibiting the mitogenic and anti-apoptotic action of IGF1 and IGF2 (20). Therefore, circulating concentrations of IGF1 could be associated with an increased risk of cancer, whereas IGFBP3 concentrations could be associated with a decreased cancer risk. IGFBP3 itself inhibits cell growth and induces apoptosis independently of the IGF1/IGF1R axis (22-25). It is also a potent inhibitor of both phosphatidylinositol 3-kinase (PI3K)/Akt and mitogen-activated protein kinase (MAPK) signaling pathways (20). Therefore, prevention strategies targeting IGF1 would be suitable only for the proportion of the population that is at increased risk due to high IGF1 levels or low IGFBP3 levels (20). The level of IGFBP3 in prostate cancer cells could be regulated by generation and degradation by proteases, such as PSA (26). IGFBP3 has also been reported to be up-regulated by potent antiproliferative and pro-apoptotic agents, including transforming growth factor- $\beta$, retinoids, tumor necrosis factor- $\alpha$, antiestrogens, 1,25-dihydroxyvitamin D3 and 5-FU (27-30).

In this study, we examined the combined anti-tumor activity of anti-androgens and 5-FU, and the synergistic mechanism underlying this combined therapy, using four prostate cancer cell lines, LNCaP, 22Rv1, DU145 and PC3. We focused on changes in hormone and growth factor dependency, such as androgens and the IGF/IGFBP axis.

\section{Materials and methods}

Reagents. Bicalutamide, an anti-androgen drug, and 5-FU were obtained from Sigma-Aldrich (St. Louis, MO, USA). Dihydrotestosterone (DHT) was obtained from Wako Pure Chemical Industries, Ltd. (Osaka, Japan). IGF1 was obtained from Becton-Dickinson Co. (Franklin Lakes, NJ, USA). 5-FU and bicalutamide were dissolved in dimethyl sulfoxide and DHT was dissolved in ethanol.

Cell lines and culture. The human prostate cancer cell lines, LNCaP, 22Rv1, DU145 and PC3, were purchased from the American Type Culture Collection (Rockville, MD, USA), and cultured in minimal essential medium (MEM; SigmaAldrich) supplemented with 5\% fetal bovine serum (FBS) (Nichirei Corp., Tokyo, Japan) or in phenol red-free RPMI1640 (Sigma-Aldrich) supplemented with 10\% dextran charcoal-stripped FBS (csFBS) (Hyclone Laboratories, Inc., Logan, UT).

Androgen or IGF1 dependency assay. To determine the optimal concentration of DHT or IGF1, cells were incubated in phenol red-free RPMI-1640 with $10 \%$ csFBS containing DHT $(0.0015,0.0046,0.014,0.041,0.12,0.37,1.11,3.33$, or $10 \mathrm{nM}$ ) for 9 days, or in serum-free MEM containing IGF1 $(12.5,25,50,100,200,400$, or $800 \mathrm{ng} / \mathrm{ml})$ for 5 days. The relative cell number was estimated by the colorimetric WST-8 assay method $(31,32)$, and calculated compared to the solvent control treatment. To assess cell proliferation at the optimal concentration of DHT or IGF1, cells were incubated in phenol red-free RPMI-1640 with $10 \%$ csFBS containing DHT for 4 days, or serum-free MEM containing IGF1 for 8 days, and cell proliferation was estimated by the crystal violet dye uptake method (33). To compare the androgen dependency or IGF1 dependency for each cell line, the relative cell growth was calculated compared to the solvent control treatment.

Cyotoxicity assay. Cells were incubated for 2 days in MEM with 5\% FBS containing 2.5-20 $\mu \mathrm{M}$ 5-FU. The relative cell number was estimated by the colorimetric WST- 8 assay method.

Complementary DNA (cDNA) preparation and real-time quantitative reverse-transcription polymerase chain reaction $(q R T-P C R)$. Total RNA was extracted using the RNeasy mini kit (Qiagen, Hilden, Germany), and reverse transcribed using the High Capacity cDNA Reverse Transcription Kit (Life Technologies, Inc., Carlsbad, CA, USA) according to the manufacturer's instructions. Two-step TaqMan real-time qRT-PCR was performed with an ABI Prism 7900 (Life Technologies). The reactions were performed at $50^{\circ} \mathrm{C}$ for $2 \mathrm{~min}$ and $95^{\circ} \mathrm{C}$ for $10 \mathrm{~min}$, followed by 40 cycles of $95^{\circ} \mathrm{C}$ for $15 \mathrm{sec}$ and $60^{\circ} \mathrm{C}$ for $1 \mathrm{~min}$. The results were normalized to $\beta$-actin levels. Primers and TaqMan probes for AR (Hs00171172_m1), IGF1R (Hs99999020_m1), IGF2R (Hs00181419_m1), epidermal growth factor receptor (EGFR) (Hs01076088_m1), human epidermal growth factor receptor 2 (Her2) (Hs01001595_m1), Her3 (Hs00176538_m1), Her4 (Hs00955525_m1), platelet-derived growth factor receptor, $\alpha$ polypeptide (PDGFRA) (Hs00998026_m1), met proto-oncogene 
Table I. Expression of growth factor receptors in prostate cancer cell lines.

\begin{tabular}{lccccccccc}
\hline & \multicolumn{7}{c}{ Relative mRNA expression level ${ }^{\mathrm{a}}$} \\
\cline { 2 - 9 } Cell line & AR & IGF1R & IGF2R & EGFR & Her2 & Her3 & Her4 & MET & PDGFRA \\
\hline LNCaP & 102 & 17 & 26 & 7.1 & 28 & 37 & 0.012 & 0.023 & 0.0020 \\
22Rv1 & 36 & 7.8 & 7.3 & 4.7 & 14 & 38 & 24 & 2.7 & n.d. \\
DU145 & n.d & 4.5 & 7.3 & 11 & 4.9 & 1.1 & 0.0037 & 16 & 12 \\
PC3 & 0.0030 & 2.5 & 6.0 & 11 & 4.3 & 1.1 & 0.20 & 55 & 0.077
\end{tabular}

amRNA levels were examined by real-time qRT-PCR and multiplied by $10^{3}$ in order to be normalized according to $\beta$-actin expression. IGF1R, IGF1 receptor; IGF2R, IGF2 receptor; n.d., not detected.

(hepatocyte growth factor receptor) (MET) (Hs00179845_m1) and $\beta$-actin (Hs99999903_m1) were prepared using TaqMan Gene Expression Assay products (Life Technologies).

Western blot analysis. Cells were harvested in protein extraction reagent (M-PER ${ }^{\mathrm{TM}}$; Pierce, Rockford, IL, USA) supplemented with protease inhibitors (Halt ${ }^{\mathrm{TM}}$ protease inhibitor cocktail kit; Pierce). Cell lysates were subjected to sodium dodecyl sulfate polyacrylamide gel electrophoresis (SDS-PAGE) and transferred to polyvinylidene fluoride (PVDF) membranes (Immobilon-P transfer membranes; Millipore, Bedford, MA, USA). After blocking, membranes were probed with primary antibodies overnight at $4^{\circ} \mathrm{C}$. Anti-AR (441), anti-IGFBP3 (H-98), anti-ALS (H-42) and anti-IGF1R $\beta$ (C-20) antibodies were obtained from Santa Cruz Biotechnology (Santa Cruz, CA, USA). Anti-phosphorylated Akt (p-Akt) [Ser473 (D9E)], anti-Akt (C67E7), anti-phosphorylated p70 S6K (p-p70 S6K) [Thr389 (10802)], anti-p70 S6K (49D7) and anti-cleaved poly (ADP-ribose) polymerase (PARP) (Asp214) antibodies were obtained from Cell Signaling Technology (Beverly, MA, USA). Anti-PSA (ER-PR8), anti-IGFBP5 (1.A.18), anti-PARP (E102) and anti- $\beta$-actin antibodies were obtained from Abcam (Cambridge, UK). The proteins were visualized using horseradish peroxidase-conjugated secondary antibodies (Cell Signaling Technology) for $1 \mathrm{~h}$ at room temperature followed by enhanced chemiluminescence (Pierce). The intensity of luminescence was quantified using a charge-coupled device camera combined with an image analysis system (LAS-3000; Fuji Film, Japan).

Enzyme-linked immunosorbent assay (ELISA). Cells were incubated for 2 days in MEM supplemented with 5\% FBS containing $0.625-20 \mu \mathrm{M} 5-\mathrm{FU}$ in $10-\mathrm{cm}$ dishes. The concentrations of IGFBP3 in the culture medium were assessed by the Quantikine ${ }^{\circledR}$ Human IGFBP-3 Immunoassay Kit (R\&D Systems, Inc., Minneapolis, MN, USA) according to the manufacturer's instructions, and the values were adjusted relative to the viable cell numbers.

Immunohistochemistry. The cells were incubated for 2 days in MEM supplemented with 5\% FBS containing $10 \mu \mathrm{M} 5-\mathrm{FU}$ in chamber slides (Becton-Dickinson Co.). Immunohistochemistry for IGFBP3 was performed using standard protocols. Briefly, the cells were fixed on slides in $100 \%$ methanol for
$10 \mathrm{~min}$. Endogenous peroxidase activity was blocked by immersing slides in $3 \%(\mathrm{v} / \mathrm{v})$ hydrogen peroxide $\left(\mathrm{H}_{2} \mathrm{O}_{2}\right)$ in methanol, then cells were blocked using goat serum, incubated with rabbit polyclonal anti-IGFBP3 antibody (H-98), stained with 3,3'-diaminobenzidine (Dako, Carpinteria, CA, USA), and counterstained with diluted Mayer's hematoxylin (Dako). Finally, cells were viewed and photographed under an inverted Olympus BX51 microscope (Olympus Corp., Tokyo, Japan) at 100,400 , or x1,000 magnification. Images were acquired using Olympus DP2-BSW software (Olympus Corp.).

Knockdown experiment with IGFBP3 small-interfering RNA (siRNA). The cells were transfected with IGFBP3 siRNA (IGFBP3-HSS179812; Life Technologies) or negative control siRNA in which the nucleotide sequence of IGFBP3 siRNA was scrambled using lipofectamine RNAiMAX (Life Technologies), and then plated in MEM with 5\% FBS and incubated overnight. On the following day, medium containing diluted bicalutamide, 5-FU, and/or IGF1 was added to the wells and cultured for another 6 days. The relative cell number was estimated by the colorimetric WST- 8 assay method, and calculated compared to the solvent control treatment.

Statistical analysis. Secreted IGFBP3 and relative cell numbers were analyzed using the Dunnett's t-test, Student's t-test and Welch's t-test with JMP® 8.0.1. software (SAS Institute Inc., Cary, NC, USA).

\section{Results}

Receptor expression profiles in four prostate cancer cell lines. The basal messenger RNA (mRNA) expression levels of nine receptors, AR, IGF1R, IGF2R, EGFR, Her2, Her3, Her4, MET and PDGFRA, related to cell growth, differentiation, mobility and drug sensitivity, were evaluated by real-time qRT-PCR (Table I). AR expression levels were approximately 3 -fold higher in LNCaP cells than 22Rv1 cells, and were relatively low in DU145 and PC3 cells. IGF1R and IGF2R were expressed in all four cell lines, and at a relatively high level in LNCaP cells. The expression level of EGFR in 22Rv1 cells was lower, and that of Her4 was higher, than in the other three cell lines. Her2 and Her3 were highly expressed in LNCaP and 22Rv1 cells compared to DU145 and PC3 cells. MET expression levels were relatively high in DU145 and PC3 


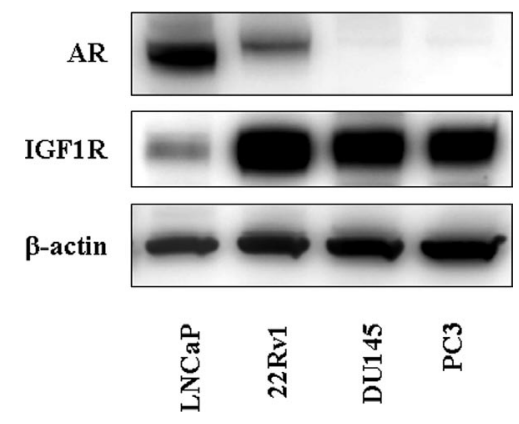

Figure 1. Cellular protein expression of AR and IGF1R in four prostate cancer cell lines. Cells were cultured in MEM supplemented with 5\% FBS for $48 \mathrm{~h}$, and cell lysates were analyzed by Western blot analysis.

cells, and low in LNCaP compared to 22Rv1 cells, while PDGFRA was expressed only in DU145 cells. The mRNA expression of other receptors, PDGFRB, vascular endothelial growth factor receptor 1 (VEGFR1), VEGFR2, VEGFR3, estrogen receptor 1 (ESR1) and ESR2, was relatively low compared to that of $\beta$-actin (data not shown).

$A R$ and IGFIR protein expression levels. Western blot analysis was used to determine AR and IGF1R protein expression levels (Fig. 1). Similar to the mRNA expression profile, the AR protein was highly expressed in LNCaP cells and moderately expressed in 22Rv1 cells, but was barely detectable in DU145 and PC3 cells. IGF1R protein expression differed from its mRNA expression, being highest in 22Rv1 cells, slightly lower in DU145 and PC3 cells, and low in LNCaP cells. The reason for this is unclear, although it could involve post-transcriptional regulation.

Cell growth androgen dependency. Following culture with optimal DHT concentrations of $0.1 \mathrm{nM}$ for 9 days, the relative cell numbers of LNCaP and 22Rv1 were increased 4-fold and 2-fold, respectively (Fig. 2A). There was little change to the DU145 and PC3 cell numbers. The cell proliferation time courses with or without DHT treatment are shown in Fig. 2B. LNCaP cells showed little proliferation in the absence of DHT, but could grow for 4 days in its presence. 22Rv1, DU145 and PC3 cells all grew in the absence of DHT. 22Rv1 growth was slightly enhanced in its presence, but DU145 and PC3 growth was unaffected. To clarify the DHT dependency of these cell lines, the time course of relative cell growth is shown in Fig. 2C. These data show that LNCaP cell growth was strongly dependent on DHT, while that of 22Rv1 was moderately DHT-dependent. DU145 and PC3 cells had no DHT dependency. The intensity of DHT dependency correlated with the AR expression levels shown in Table I and Fig. 1.

IGF1 dependency and cell growth. Following culture with IGF1 for 5 days, relative cell numbers were determined as shown in Fig. 3A. The growth of 22Rv1, DU145, and PC3 cells was stimulated 1.4- to 2.2-fold by IGF1, although there was no clear optimal IGF1 concentration within the range of 10 to $1,000 \mathrm{ng} / \mathrm{ml}$. LNCaP cell growth was barely stimulated. The cell proliferation time courses with or without IGF1 treatment are shown in Fig. 3B. 22Rv1, DU145 and PC3 cell growth was enhanced by IGF1, but there was no effect on LNCaP cells. To clarify the IGF1 dependency of these cell lines, the time course of relative cell growth is shown in Fig. 3C. The relative LNCaP cell number was almost $100 \%$ during the culture period, while the relative cell numbers of 22Rv1, DU145 and PC3 increased in a time-dependent manner. These data demonstrate that the 22Rv1, DU145 and PC3 cell growth, but not that of the LNCaP cells, was IGF1-dependent.

Effect of 5-FU on cellular IGFBP3 expression and secreted $I G F B P 3$. We assessed changes in IGFBP3 expression and related factors after treatment with 5-FU for $48 \mathrm{~h}$ using Western blot analysis (Fig. 4B). Prior to this experiment, we measured 5-FU sensitivity in the four prostate cell lines (Fig. 4A). IGFBP3 protein expression was up-regulated in a dose-dependent manner in DU145 and PC3 cells when treated with 5-FU, although its expression in LNCaP and 22Rv1 cells treated with 10 and $20 \mu \mathrm{M} 5-\mathrm{FU}$ was lower than in the cells treated with 2.5 or $5 \mu \mathrm{M} 5-\mathrm{FU}$, which could reflect toxicity at higher concentrations. However, IGFBP5 protein expression was not detected in LNCaP and 22Rv1 cells. IGFBP5 was detectable in DU145 cells, but was unchanged following 5-FU treatment. IGFBP5 expression in PC3 cells increased slightly when treated with 5 and $20 \mu \mathrm{M}$ but not $10 \mu \mathrm{M} 5$-FU. Therefore, IGFBP5 expression levels were less strongly up-regulated by 5-FU compared to IGFBP3, although IGFBP5 was slightly up-regulated in PC3 cells.

All four prostate cancer cell lines expressed the IGF1R protein, and only the IGF1R expression in PC3 cells was altered by 5 -FU treatment, decreasing until it reached approximately $10 \%$. The AR protein expression in LNCaP cells was unchanged, but that in $22 \mathrm{Rv} 1$ cells was decreased by $5-\mathrm{FU}$. AR protein was not detected in DU145 or PC3 cells.

PSA is not only a biomarker of prostate cancer progression, but also has hydrolytic activity and degrades IGFBP3. PSA expression in LNCaP cells was unchanged following treatment with up to $5 \mu \mathrm{M}$ of $5-\mathrm{FU}$, that in $22 \mathrm{Rv} 1$ cells was slightly up-regulated, and no PSA was detected in DU145 and PC3 cells. ALS protein expression increased in PC3 cells but not in the other three cell lines after treatment with 5-FU.

To confirm the alterations of IGFBP3 protein expression caused by 5 -FU, IGFBP3 protein was detected using immunohistochemistry in PC3 cells treated with or without 5-FU for $48 \mathrm{~h}$ (Fig. 4C). IGFBP3 that was mainly expressed in the cytoplasm was up-regulated after 5-FU treatment. The concentration of IGFBP3 secreted in the culture medium was measured by ELISA. The secreted IGFBP3 concentrations of all four cell lines increased in a 5-FU concentration-dependent manner (Fig. 4D). The IGFBP3 concentrations in the culture medium were $3.9,2.2$ and $8 \mathrm{ng} / 10^{5}$ cells for $22 \mathrm{Rv1}$, DU145 and PC3 cells, respectively. However, LNCaP cells expressed IGFBP 3 at a concentration of just $0.2 \mathrm{ng} / 10^{5}$ cells.

Effects of 5-FU on IGF1/IGF1R signaling. To confirm the hypothesis that 5-FU induces IGFBP3 expression and eventually suppresses the IGF1/IGF1R axis, we determined whether 5-FU suppressed the expression of p-Akt and p-p70 S6K downstream of IGF1/IGF1R signaling. After treatment with or without 5-FU, PC3 cells were stimulated by IGF1, and 
A
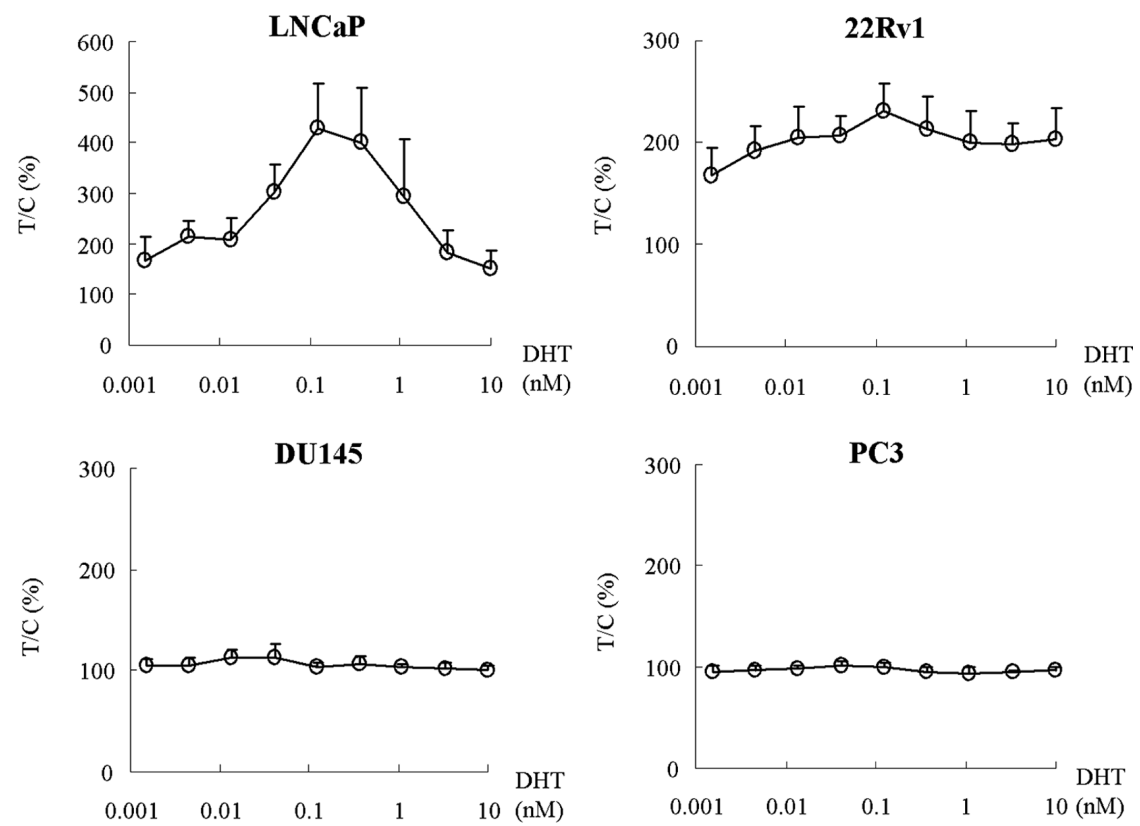

B
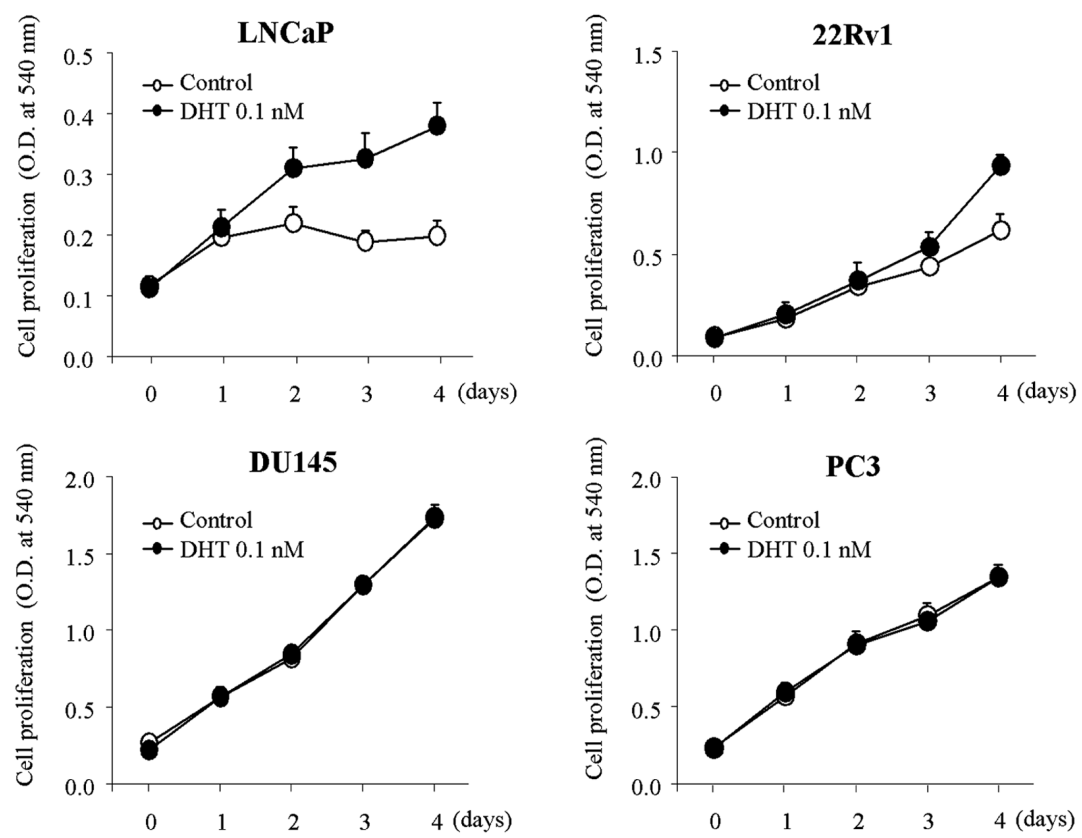

C

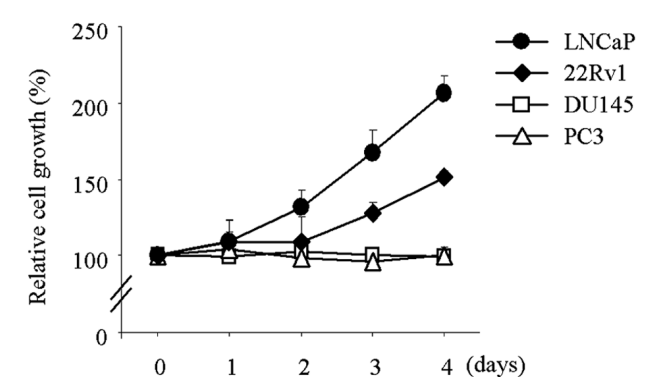

Figure 2. Androgen dependency of prostate cancer cell proliferation. (A) Cell proliferation relative to DHT concentration. Cells were cultured in phenol red-free medium supplemented with $10 \%$ csFBS and $0.0015-10 \mathrm{nM}$ DHT for 9 days. The cell number was estimated by colorimetric WST-8 assay (n=6) [the relative cell number (T/C) was defined as the ratio of the cell number in the DHT-treated group (T) compared to that in the non-treated control group (C)]. (B) Growth curves of cell lines with or without DHT. Cells were cultured in phenol red-free medium supplemented with $10 \%$ csFBS with or without 0.1 nM DHT for 4 days. Cell numbers were estimated by crystal violet dye-uptake $(n=6)$. (C) Time course of relative cell number of prostate cancer cells treated with 0.1 nM DHT compared to the non-DHT-treatment group. 
A
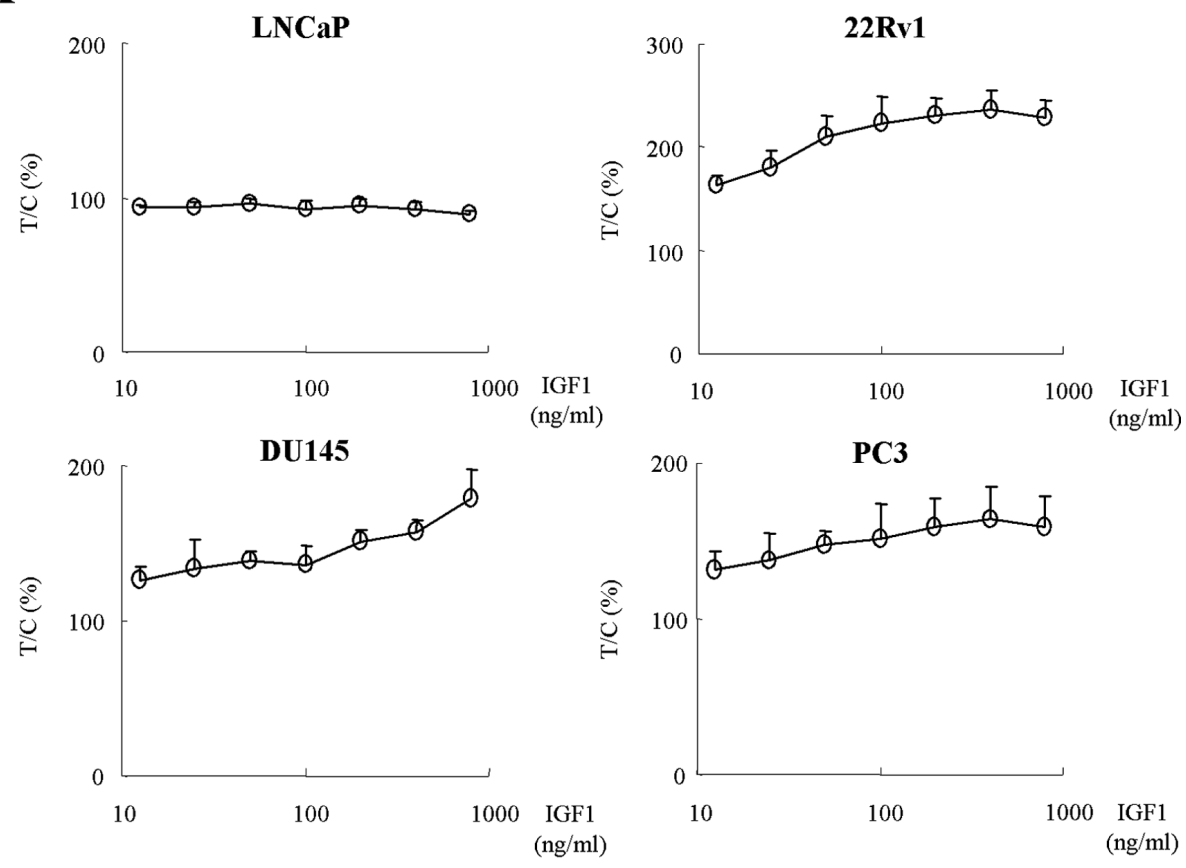

B
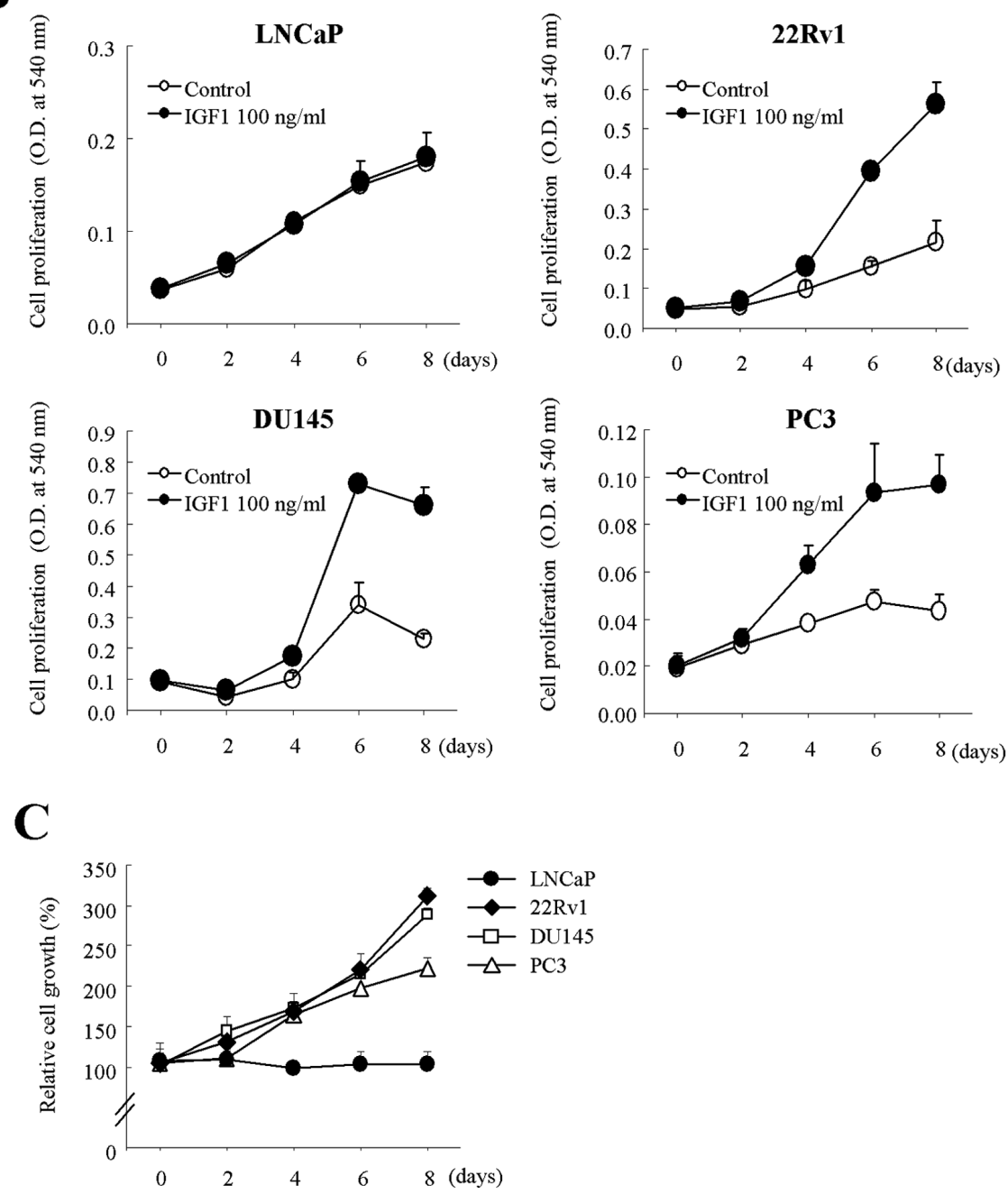

Figure 3. IGF1 dependency of prostate cancer cell proliferation. (A) Cell proliferation relative to IGF1 concentration. Cells were cultured in phenol red-free medium supplemented with 5\% FBS with $12.5-800 \mathrm{ng} / \mathrm{ml}$ IGF1 for 5 days. The cell number was estimated by colorimetric WST-8 assay (n=6), and the relative cell number was calculated as described previously. (B) Growth curves of cell lines with or without IGF1. Cells were cultured in MEM medium supplemented with $5 \%$ FBS with or without $100 \mathrm{ng} / \mathrm{ml}$ IGF1 for 8 days. Cell numbers were estimated by crystal violet dye-uptake (n=6). (C) Time course of relative cell number of prostate cancer cells treated with $100 \mathrm{ng} / \mathrm{ml}$ IGF1 compared to the non-IGF1-treatment group. 


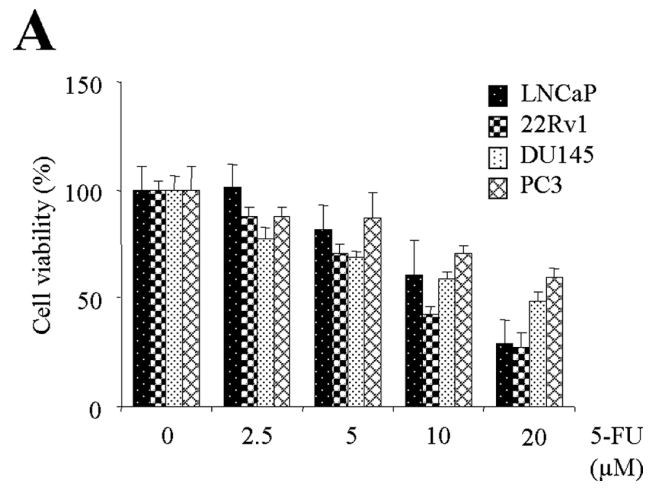

\section{B}
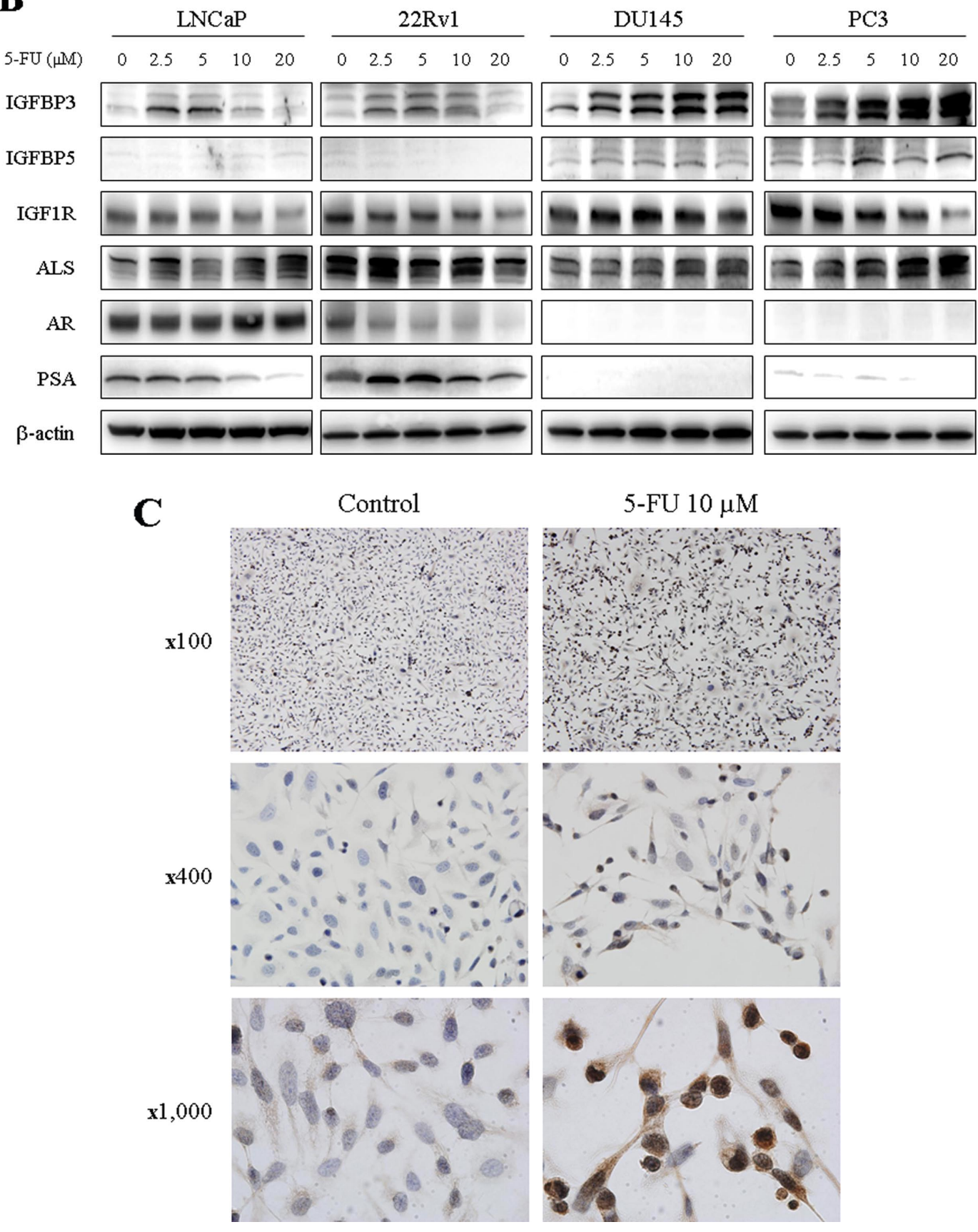

Figure 4. Up-regulation of IGFBP3 protein following 5-FU treatment. (A) Cell viability of prostate cell lines treated with 5-FU for $48 \mathrm{~h}$. Cells were cultured in MEM supplemented with 5\% FBS with 2.5-20 $\mu \mathrm{M}$ 5-FU for 2 days. The cell number was estimated by colorimetric WST-8 assay (n=6), and the cell viability relative to the non-treated control group was calculated. (B) Cellular protein expression of IGF1 or AR axis-related factors in four prostate cell lines after 5-FU treatment. Cells were cultured in MEM medium supplemented with 5\% FBS with 2.5-20 $\mu \mathrm{M}$ 5-FU for $48 \mathrm{~h}$. Cell lysates were used for Western blot analysis. (C) Cellular expression of IGFBP3 in PC3 cells treated with or without $10 \mu \mathrm{M} 5$-FU detected by immunohistochemistry. Representative images of control and $10 \mu \mathrm{M}$ 5-FU-treated cells (magnification, 100, 400 and x1,000). 
D
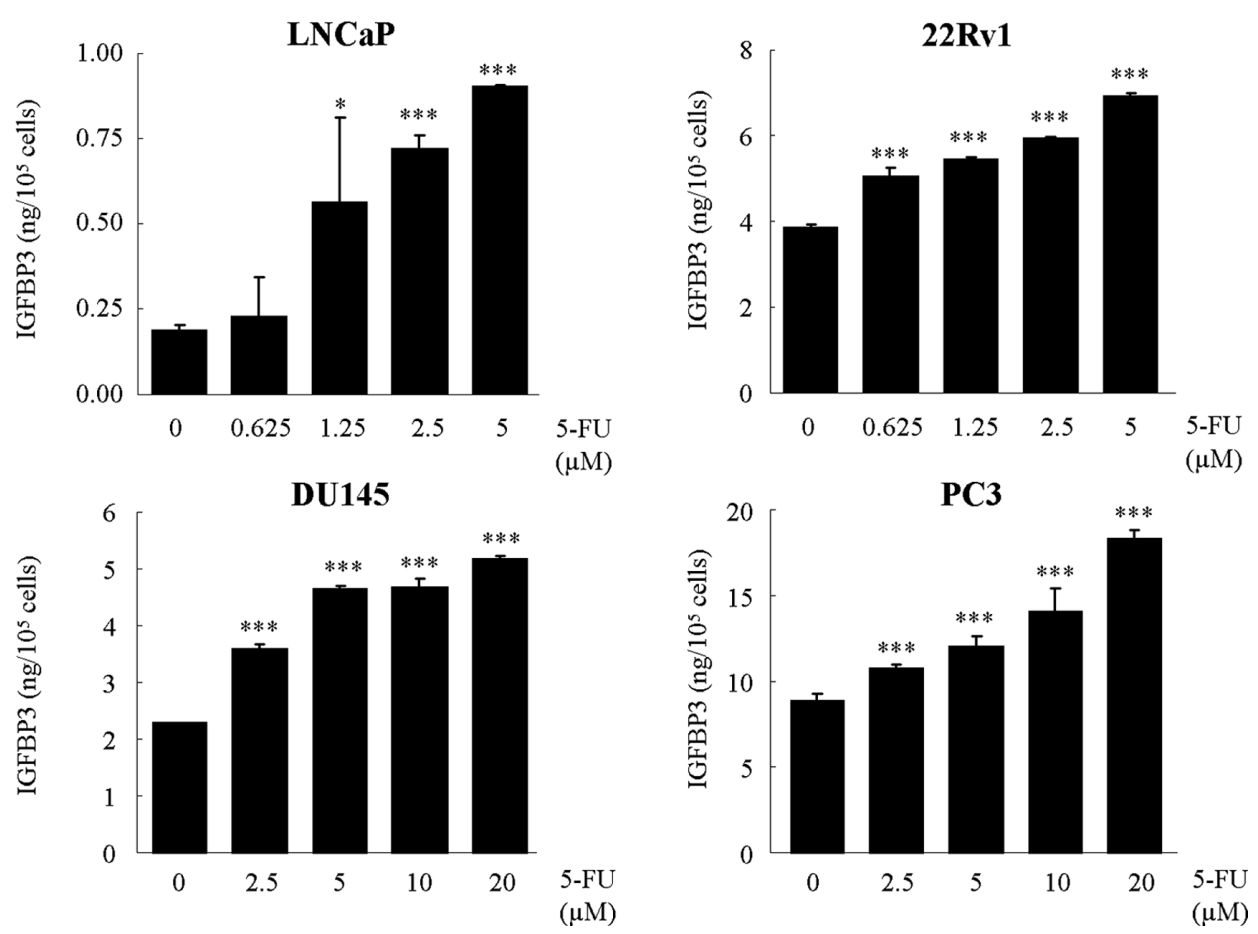

Figure 4 (Continued). (D) Secreted IGFBP3 following 5-FU treatment for $48 \mathrm{~h}$. Cells were cultured in MEM medium supplemented with 5\% FBS with $0.625-20 \mu \mathrm{M} 5$-FU for $48 \mathrm{~h}$. Supernatants of cultured medium analyzed by ELISA. Statistical analysis was performed using Dunnett's t-test. Significant differences from the control are shown as ${ }^{*} \mathrm{p}<0.05$ and $^{* * *} \mathrm{p}<0.001$.
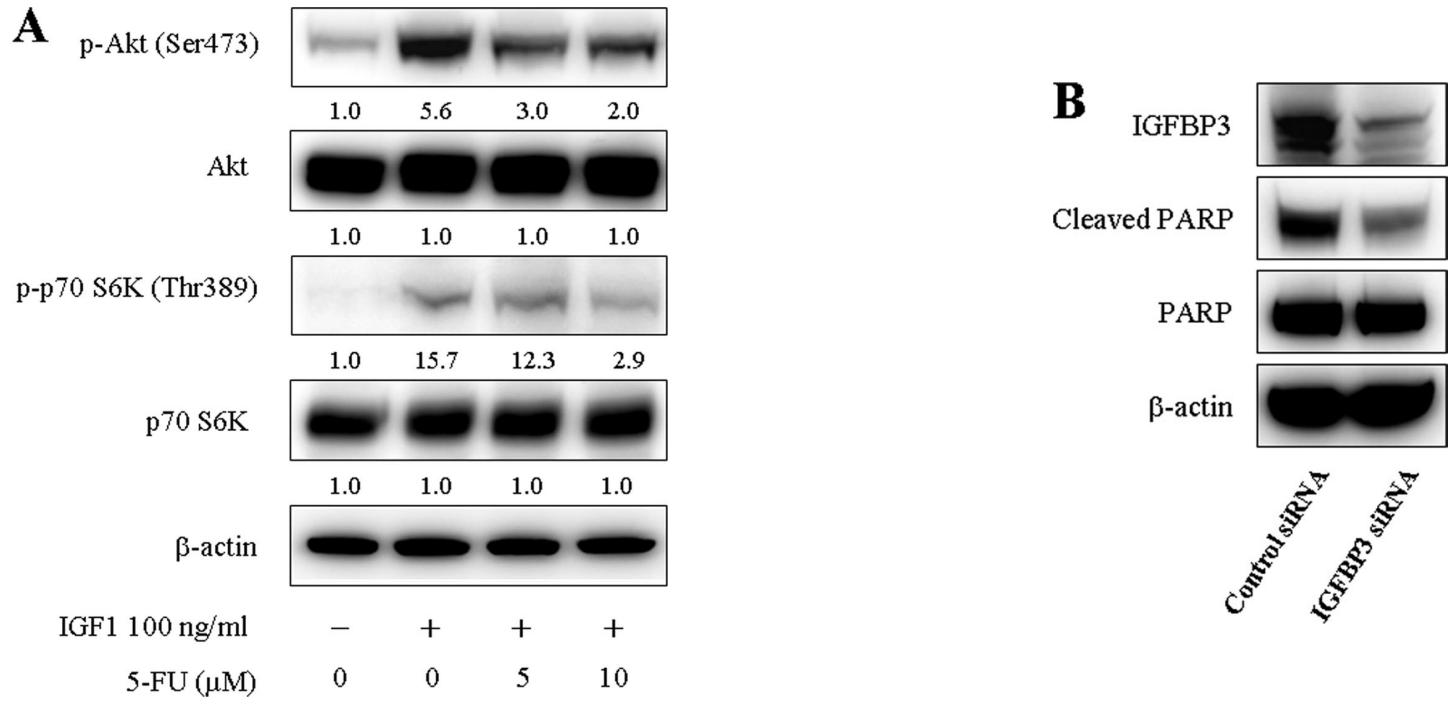

Figure 5. Influence of 5-FU on IGFBP3, reducing IGF1 signal and inducing apoptosis in PC3 cells. (A) Effects of 5-FU on IGF1/IGF1R signaling. Cells were treated with 5 or $10 \mu \mathrm{M} 5$-FU in serum-free MEM medium for $48 \mathrm{~h}$, then stimulated with $100 \mathrm{ng} / \mathrm{ml} \mathrm{IGF1} \mathrm{for} 30$ min. Cell lysates were analyzed for p-Akt, Akt, p-p70 S6K and p70 S6K expression by immunoblotting. (B) Influence of interfering IGFBP3 up-regulation by 5-FU on apoptosis induction. IGFBP3-specific or control siRNA duplexes were transfected into PC3 cells. Cells were cultured in MEM medium supplemented with 5\% FBS with $10 \mu \mathrm{M} 5$-FU for 48 h. Cell lysates were analyzed for protein expression of IGFBP3, cleaved PARP and PARP by Western blot analysis.

p-Akt, Akt, p-p70 S6K and p70 S6K were evaluated by Western blot analysis. p-Akt was up-regulated to $560 \%$ (compared to basal levels of $100 \%$ ) by IGF1, and downregulated to 300 or $200 \%$ by 5 or $10 \mu \mathrm{M} 5$-FU (Fig. $5 \mathrm{~A}$ ). The expression of p-p70 S6K was up-regulated to $1,570 \%$ by IGF1 and down-regulated to $290 \%$ when treated with $10 \mu \mathrm{M} 5-\mathrm{FU}$.
These data suggest that 5-FU-induced IGFBP3 expression could repress the IGF1 signal.

Influence of IGFBP3 siRNA on 5-FU-induced apoptosis. To clarify whether 5-FU-induced IGFBP3 expression contributed to the apoptosis caused by 5-FU, the levels of PARP cleaved 

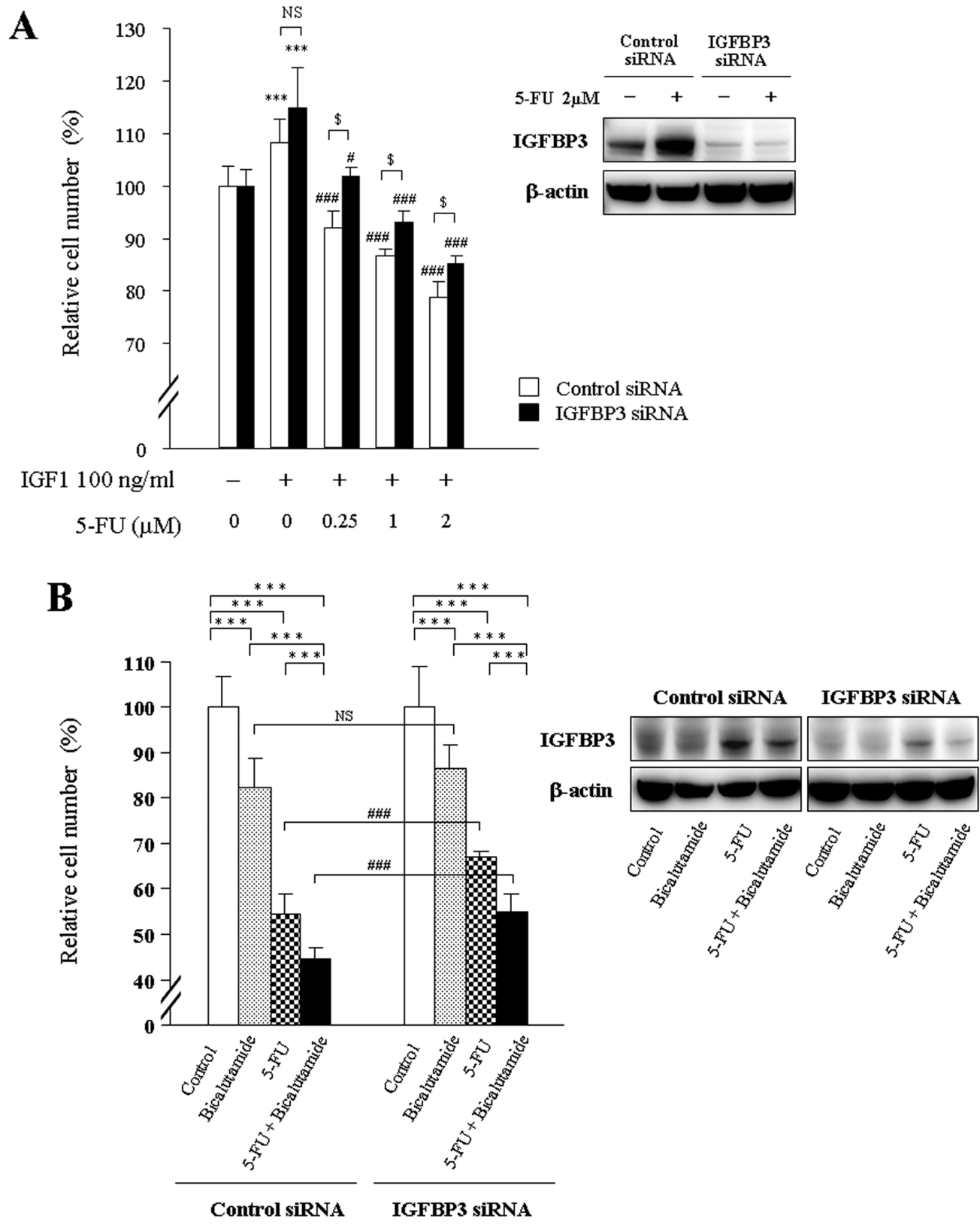

Figure 6. Effects of IGFBP3 gene silencing on the growth inhibitory effects of 5-FU alone and in combination with bicalutamide. (A) Effect on cell growth of reducing IGFBP3 expression by IGF1 with or without 5-FU in PC3 cells. IGFBP3-specific or control siRNA duplexes were transfected into PC 3 cells. Cells were cultured in MEM medium supplemented with 5\% FBS and $100 \mathrm{ng} / \mathrm{ml} \mathrm{IGF1} \mathrm{with} \mathrm{or} \mathrm{without} \mathrm{0.25-2} \mu \mathrm{M}$ 5-FU for $144 \mathrm{~h}$. Measurements were made in triplicate. The cell number was calculated relative to the 5 -FU non-treated control. Each bar represents the mean \pm standard deviation $(\mathrm{SD})(\mathrm{n}=3)$. Significant differences are shown as ${ }^{* * *} \mathrm{p}<0.001$ by Dunnett's t-test (compared to the control), ${ }^{\#} \mathrm{p}<0.05$, ${ }^{\# \# \#} \mathrm{p}<0.001$ by Dunnett's t-test (compared to the IGF1-treated group), and ${ }^{\$} \mathrm{p}<0.05$ by Welch's t-test (compared to the control siRNA-treated group and the IGFBP3 siRNA-treated group at respective doses of 5-FU). (B) Combined antiproliferative effects of 5-FU and bicalutamide in IGFBP3-specific or control siRNA duplex-transfected 22Rv1 cells. Cells were cultured in MEM medium supplemented with 5\% FBS. After adhesion, cells were grown in $3.2 \mu \mathrm{M}$ bicalutamide and/or $1 \mu \mathrm{M} 5$-FU for $144 \mathrm{~h}$. Measurements were repeated 6 times. The cell number was calculated relative to the 5-FU non-treated control. Significant differences are shown as ${ }^{* * * *} \mathrm{p}<0.001$ by Student's t-test (compared to the control) and ${ }^{\# \# \#} \mathrm{p}<0.001$ by Welch's t-test (compared to the control siRNA-treated group and the IGFBP3 siRNA-treated group).

by 5 -FU in PC3 cells treated with IGFBP3 siRNA or control siRNA, were evaluated. IGFBP3 siRNA decreased the levels of cleaved PARP induced by 5 -FU by approximately one-half (Fig. 5B), suggesting that 5-FU-induced apoptosis could, in part, be dependent on IGFBP3 up-regulation by 5-FU.

Effects of IGFBP3 gene silencing on the growth inhibitory effects of 5-FU alone and in combination with bicalutamide. We then examined whether 5-FU activity was reduced following IGFBP3 siRNA treatment (Fig. 6A). IGF1 significantly stimulated PC3 cell growth and 5-FU inhibited cell growth in a dose-dependent manner. After treatment with IGFBP3 siRNA, the growth inhibitory effects of 5-FU were reduced by approximately $10 \%$ compared to the control siRNA.

We then evaluated the effects of IGFBP3 gene silencing on the growth inhibitory activity of 5-FU combined with bicalutamide on 22Rv1 cells (Fig. 6B). Bicalutamide alone and 5-FU alone inhibited cell growth by 82.3 and $54.5 \%$, respectively, compared to the control. Combined treatment with bicalutamide and 5-FU reduced growth by $44.6 \%$ 
compared to the control. By silencing the IGFBP3 gene using siRNA, the growth inhibitory activities of 5-FU alone and in combination with bicalutamide were reduced by about $10 \%$ compared to the control. However, bicalutamide alone showed similar activity in the treatment with or without IGFBP3 siRNA.

\section{Discussion}

In the present study, we examined the effects of second-line MAB therapy combined with 5-FU on CRPC, focusing on androgen or IGF1 dependency. We used four independently established and widely used prostate cancer cell lines, LNCaP, 22Rv1, DU145 and PC3, to determine the basal expression levels of several putative receptors related to proliferation (Table I and Fig. 1), and the growth dependencies on DHT (Fig. 2) and IGF1 (Fig. 3).

LNCaP cells expressed the highest AR levels and the lowest IGF1R levels among the four cell lines tested, and the growth of these cells was strongly dependent on androgens but not IGF1. In contrast, PC3 and DU145 cells expressing high levels of IGF1R and relatively low levels of AR, were strongly stimulated by IGF1 but not androgens. The growth of 22Rv1 cells with moderate expression levels of AR and IGF1R was dependent on both androgens and IGF1. Therefore, the growth signals of androgens and IGF1 in prostate cancer cell lines are mutually supplemented. These data suggest that prostate cancer cells could change their dependency from DHT to another growth factor, such as IGF1, while reducing their sensitivity to androgens and acquiring resistance against antiandrogens. Indeed, Nickerson et al reported that progression to androgen independence is associated with the elevated expression of IGF1 mRNA, reduced IGFBP3 expression and increased IGF1R phosphorylation (34). Higher circulating levels of IGF1 have been reported in prostate cancer (21). In addition, many studies have shown a correlation between IGF1R expression and poor prognosis (34-36), while other in vitro experiments have implicated IGF1R expression in the progression of prostate cancers $(37,38)$.

The availability of unbound IGF1 for interaction with IGF1R is modulated by IGFBPs. These proteins negatively regulate IGF1: They can sequester IGF1 from IGF1R as they have a greater affinity for the former (27). Of the six members of the IGFBP family, IGFBP3 has growth inhibitory and apoptosis-inducing activities (27,39). IGFBP3 and IGFBP5 circulate predominantly in a ternary complex with IGF and ALS. We therefore examined whether IGFBP3 and IGFBP5, as representative IGFBPs for IGF1, were affected by treatment with 5-FU. When the four prostate cancer cell lines were treated with 5-FU, IGFBP3 was up-regulated intracellularly, especially in the cytoplasm, and in the culture medium of all tested cell lines (Fig. 4B-D). In particular, IGFBP3 was increased much more in the androgen-independent cell lines, PC3 and DU145, than in the androgen-dependent cell lines, LNCaP and 22Rv1. This could reflect the fact that the inducibility of IGFBP3 by 5-FU is proportional to the grade of IGF1 dependency and/or androgen independency.

Certain studies have shown that natural products and drugs including 5-FU can increase levels of IGFBP3. Patel et al reported that curcumin, which is the major ingredient of turmeric, and 5-FU markedly increased IGFBP levels in the colon cancer cell line, HCT-116, by 2.1- and 3.2-fold, respectively (29). Kanagaraj et al demonstrated that the carotenoid lycopene down-regulated IGF1R and up-regulated IGFBP3 in PC3 cells, induced apoptosis, and eventually inhibited cell growth (40). Liu et al also suggested that lycopene can mediate its protective effects against smoke-induced lung carcinogenesis in ferrets by up-regulating IGFBP3 and downregulating the phosphorylation of $\mathrm{BAD}$, which is a member of the BH3-only subfamily of Bcl-2 (41). Shukla et al found that orally administered apigenin, which is a dietary flavonoid that is abundant in fruit and vegetables, increased IGFBP3 gene expression and secretion, reduced IGF1 levels in prostate cancer and in 22Rv1 cells in nude mouse xenografts, induced apoptosis and inhibited tumor growth (42).

Patel et al also reported that the observed increase in IGFBP3 expression caused by 5-FU treatment is restricted to p53-positive cells, suggesting a role for this tumor suppressor gene in regulating IGFBP3 (29). Two p53-responsive elements have been identified in the IGFBP3 gene, which bind highly purified wild-type p53 but not mutant p53 (43). In the present study, 5-FU markedly increased IGFBP3 levels by 2- to 8-fold not only in the p53 wild-type cell line LNCaP, but also in three p53-mutated cell lines (PC3, 22Rv1 and DU145). We therefore concluded that the up-regulation of IGFBP 3 by 5-FU does not depend on p53.

IGFBP3 attenuated the signal transduction of IGF1, such as IGF1-induced Akt activation, by blockade of the IGF1/ IGF1R axis. Our data showed that 5-FU decreased the levels of p-Akt and p-p70 S6K, which were the downstream targets of IGF1/IGF1R, after IGF1 stimulation in PC3 cells (Fig. 5A). The down-regulation of IGF1R could thus be related to the up-regulation of IGFBP3 in PC3 cells. Moreover, IGFBP3 induces apoptosis by its ability to bind IGFs as well as its IGF-independent effects involving binding to other molecules such as the retinoid X receptor- $\alpha$ (RXR- $\alpha)(44,45)$. We confirmed that the siRNA inhibition of IGFBP3 led to decreased levels of cleaved PARP induced by 5-FU (Fig. 5B), and increased the relative number of PC3 cells stimulated by IGF1 (Fig. 6A). We also showed that siRNA inhibition of IGFBP3 decreased the combined cytotoxic effect of bicalutamide and 5-FU in 22Rv1 cells (Fig. 6B). These findings suggest that IGFBP3 expression induced by 5 -FU contributes to the synergistic effect of bicalutamide combined with 5-FU on prostate cancer cells with both androgen and IGF1 growth dependency.

Chemotherapy including 5-FU or its derivatives could induce IGFBP3 expression not only in prostate cancer but also in various types of malignant tumor, thereby prolonging the survival period if the tumor growth is IGF1-dependent. The up-regulation of IGFBP3 by 5-FU is critical for CRPC treatments involving combined 5-FU and anti-androgen drugs, as androgendeprivation therapy is usually administered for prostate cancer and changes the growth dependency from androgens to IGF1. The up-regulation of IGFBP3 by 5-FU could contribute to the potent combined effect of second-line MAB and UFT against CRPC, as was reported at the 2010 ASCO annual meeting. Further study is required to clarify whether the up-regulation of IGFBP3 by 5-FU is clinically important for the potent activity of UFT combined with second-line MAB therapy in prolonging the PFS time of CRPC patients. 
In conclusion, our study demonstrates that the synergistic effect of 5-FU combined with anti-androgen drugs on prostate cancer cells with androgen and IGF1 growth dependency is mediated through the 5-FU-induced up-regulation of IGFBP3. If the up-regulation of IGFBP3 overcomes CRPC, MAB combined with 5-FU could be an attractive anti-cancer strategy. The translation of this in vitro result into a clinical application could have a great impact on the selection of the best treatment modality for the individual patient with CRPC. To select the responders to second-line MAB therapy combined with 5-FU, the development of a practical method for determining the up-regulation of IGFBP3 should be the subject of further research.

\section{Acknowledgements}

We thank Dr Taiji Hayashi (Tokushima Research Center, Taiho Pharmaceutical Co. Ltd., Japan) for fruitful discussions.

\section{References}

1. Ferlay J, Shin HR, Bray F, Forman D, Mathers C and Parkin DM: Estimates of worldwide burden of cancer in 2008: GLOBOCAN 2008. Int J Cancer: June 17, 2010 (Epub ahead of print).

2. Namiki M, Akaza H, Lee SE, et al: Prostate Cancer Working Group report. Jpn J Clin Oncol 40 (Suppl 1): i70-i75, 2010.

3. Maximum androgen blockade in advanced prostate cancer: an overview of the randomised trials. Prostate Cancer Trialists' Collaborative Group. Lancet 355: 1491-1498, 2000.

4. Schmitt B, Wilt TJ, Schellhammer PF, et al: Combined androgen blockade with nonsteroidal antiandrogens for advanced prostate cancer: a systematic review. Urology 57: 727-732, 2001.

5. Miyake H, Hara I and Eto H: Clinical outcome of maximum androgen blockade using flutamide as second-line hormonal therapy for hormone-refractory prostate cancer. BJU Int 96: 791-795, 2005.

6. Nishimura K, Arichi N, Tokugawa S, Yoshioka I, Kishikawa H and Ichikawa Y: Effects of flutamide as a second-line agent for maximum androgen blockade of hormone refractory prostate cancer. Int J Urol 14: 264-267, 2007.

7. Tannock IF, de Wit R, Berry WR, et al: Docetaxel plus prednisone or mitoxantrone plus prednisone for advanced prostate cancer. $\mathrm{N}$ Engl J Med 351: 1502-1512, 2004.

8. Petrylak DP, Tangen CM, Hussain MH, et al: Docetaxel and estramustine compared with mitoxantrone and prednisone for advanced refractory prostate cancer. N Engl J Med 351: 1513-1520, 2004.

9. Agoulnik IU and Weigel NL: Androgen receptor action in hormone-dependent and recurrent prostate cancer. J Cell Biochem 99: 362-372, 2006

10. Zhang L, Johnson M, Le KH, et al: Interrogating androgen receptor function in recurrent prostate cancer. Cancer Res 63: 4552-4560, 2003.

11. Guo Z, Yang X, Sun F, et al: A novel androgen receptor splice variant is up-regulated during prostate cancer progression and promotes androgen depletion-resistant growth. Cancer Res 69 2305-2313, 2009.

12. Dehm SM, Schmidt LJ, Heemers HV, Vessella RL and Tindall DJ: Splicing of a novel androgen receptor exon generates a constitutively active androgen receptor that mediates prostate cancer therapy resistance. Cancer Res 68: 5469-5477, 2008.

13. Locke JA, Guns ES, Lubik AA, et al: Androgen levels increase by intratumoral de novo steroidogenesis during progression of castration-resistant prostate cancer. Cancer Res 68: 6407-6415, 2008.

14. Dillard PR, Lin MF and Khan SA: Androgen-independent prostate cancer cells acquire the complete steroidogenic potential of synthesizing testosterone from cholesterol. Mol Cell Endocrinol 295: 115-120, 2008.

15. Grossmann ME, Huang $\mathrm{H}$ and Tindall DJ: Androgen receptor signaling in androgen-refractory prostate cancer. J Natl Cancer Inst 93: 1687-1697, 2001.

16. Zhu ML and Kyprianou N: Androgen receptor and growth factor signaling cross-talk in prostate cancer cells. Endocr Relat Cancer 15: 841-849, 2008.
17. Culig Z, Hobisch A, Cronauer MV, et al: Androgen receptor activation in prostatic tumor cell lines by insulin-like growth factor-I, keratinocyte growth factor, and epidermal growth factor. Cancer Res 54: 5474-5478, 1994.

18. Orio F Jr, Terouanne B, Georget V, et al: Potential action of IGF-1 and EGF on androgen receptor nuclear transfer and transactivation in normal and cancer human prostate cell lines. Mol Cell Endocrinol 198: 105-114, 2002.

19. Burfeind P, Chernicky CL, Rininsland F, Ilan J and Ilan J: Antisense RNA to the type I insulin-like growth factor receptor suppresses tumor growth and prevents invasion by rat prostate cancer cells in vivo. Proc Natl Acad Sci USA 93: 7263-7268, 1996.

20. Djavan B, Waldert M, Seitz C and Marberger M: Insulin-like growth factors and prostate cancer. World J Urol 19: 225-233, 2001.

21. LeRoith D and Roberts CT Jr: The insulin-like growth factor system and cancer. Cancer Lett 195: 127-137, 2003.

22. Liu B, Lee HY, Weinzimer SA, et al: Direct functional interactions between insulin-like growth factor-binding protein-3 and retinoid $\mathrm{X}$ receptor-alpha regulate transcriptional signaling and apoptosis. J Biol Chem 275: 33607-33613, 2000.

23. Zappala G, Elbi C, Edwards J, Gorenstein J, Rechler MM and Bhattacharyya N: Induction of apoptosis in human prostate cancer cells by insulin-like growth factor binding protein-3 does not require binding to retinoid $\mathrm{X}$ receptor-alpha. Endocrinology 149: 1802-1812, 2008

24. Shahjee H, Bhattacharyya N, Zappala G, Wiench M, Prakash S and Rechler MM: An N-terminal fragment of insulin-like growth factor binding protein-3 (IGFBP-3) induces apoptosis in human prostate cancer cells in an IGF-independent manner. Growth Horm IGF Res 18: 188-197, 2008.

25. Bhattacharyya N, Pechhold K, Shahjee H, et al: Nonsecreted insulin-like growth factor binding protein-3 (IGFBP-3) can induce apoptosis in human prostate cancer cells by IGF-independent mechanisms without being concentrated in the nucleus. J Biol Chem 281: 24588-24601, 2006.

26. Cohen P, Graves HC, Peehl DM, Kamarei M, Giudice LC and Rosenfeld RG: Prostate-specific antigen (PSA) is an insulin-like growth factor binding protein-3 protease found in seminal plasma. J Clin Endocrinol Metab 75: 1046-1053, 1992.

27. Yamada PM and Lee KW: Perspectives in mammalian IGFBP-3 biology: local vs. systemic action. Am J Physiol Cell Physiol 296: C954-C976, 2009.

28. Peehl DM, Krishnan AV and Feldman D: Pathways mediating the growth-inhibitory actions of vitamin D in prostate cancer. J Nutr 133: S2461-S2469, 2003.

29. Patel BB, Sengupta R, Qazi S, et al: Curcumin enhances the effects of 5-fluorouracil and oxaliplatin in mediating growth inhibition of colon cancer cells by modulating EGFR and IGF-1R. Int J Cancer 122: 267-273, 2008.

30. Gucev ZS, Oh Y, Kelley KM and Rosenfeld RG: Insulin-like growth factor binding protein 3 mediates retinoic acid- and transforming growth factor beta2-induced growth inhibition in human breast cancer cells. Cancer Res 56: 1545-1550, 1996.

31. Ishiyama M, Miyazono Y, Sasamoto K, Ohkura Y and Ueno K: A highly water-soluble disulfonated tetrazolium salt as a chromogenic indicator for NADH as well as cell viability. Talanta 44: 1299-1305, 1997.

32. Miyamoto T, Min W and Lillehoj HS: Lymphocyte proliferation response during Eimeria tenella infection assessed by a new, reliable, nonradioactive colorimetric assay. Avian Dis 46: 10-16, 2002.

33. Saotome K, Morita H and Umeda M: Cytotoxicity test with simplified crystal violet staining method using microtitre plates and its application to injection drugs. Toxicol In Vitro 3: 317-321, 1989.

34. Nickerson T, Chang F, Lorimer D, Smeekens SP, Sawyers CL and Pollak M: In vivo progression of LAPC-9 and LNCaP prostate cancer models to androgen independence is associated with increased expression of insulin-like growth factor I (IGF-I) and IGF-I receptor (IGF-IR). Cancer Res 61: 6276-6280, 2001.

35. Hakam A, Yeatman TJ, Lu L, et al: Expression of insulin-like growth factor-1 receptor in human colorectal cancer. Hum Pathol 30: $1128-1133,1999$.

36. Turner BC, Haffty BG, Narayanan L, et al: Insulin-like growth factor-I receptor overexpression mediates cellular radioresistance and local breast cancer recurrence after lumpectomy and radiation. Cancer Res 57: 3079-3083, 1997.

37. Tanno S, Tanno S, Mitsuuchi Y, Altomare DA, Xiao GH and Testa JR: AKT activation up-regulates insulin-like growth factor I receptor expression and promotes invasiveness of human pancreatic cancer cells. Cancer Res 61: 589-593, 2001. 
38. Grzmil M, Hemmerlein B, Thelen P, Schweyer S and Burfeind P. Blockade of the type I IGF receptor expression in human prostate cancer cells inhibits proliferation and invasion, up-regulates IGF binding protein-3, and suppresses MMP-2 expression. J Pathol 202: 50-59, 2004.

39. Ali O, Cohen P and Lee KW: Epidemiology and biology of insulin-like growth factor binding protein-3 (IGFBP-3) as an anti-cancer molecule. Horm Metab Res 35: 726-733, 2003.

40. Kanagaraj P, Vijayababu MR, Ravisankar B, Anbalagan J, Aruldhas MM and Arunakaran J: Effect of lycopene on insulinlike growth factor-I, IGF binding protein-3 and IGF type-I receptor in prostate cancer cells. J Cancer Res Clin Oncol 133: 351-359, 2007.

41. Liu C, Lian F, Smith DE, Russell RM and Wang XD: Lycopene supplementation inhibits lung squamous metaplasia and induces apoptosis via up-regulating insulin-like growth factor-binding protein 3 in cigarette smoke-exposed ferrets. Cancer Res 63: $3138-3144,2003$
42. Shukla S, Mishra A, Fu P, MacLennan GT, Resnick MI and Gupta S: Up-regulation of insulin-like growth factor binding protein-3 by apigenin leads to growth inhibition and apoptosis of 22Rv1 xenograft in athymic nude mice. FASEB J 19: 2042-2044, 2005.

43. Buckbinder L, Talbott R, Velasco-Miguel S, et al: Induction of the growth inhibitor IGF-binding protein 3 by p53. Nature 377: 646-649, 1995.

44. Lee KW, Cobb LJ, Paharkova-Vatchkova V, Liu B, Milbrandt J and Cohen P: Contribution of the orphan nuclear receptor Nur77 to the apoptotic action of IGFBP-3. Carcinogenesis 28: 1653-1658, 2007.

45. Lee KW, Ma L, Yan X, Liu B, Zhang XK and Cohen P: Rapid apoptosis induction by IGFBP-3 involves an insulin-like growth factor-independent nucleomitochondrial translocation of RXRalpha/Nur77. J Biol Chem 280: 16942-16948, 2005. 